\title{
Refining the interpretation of oxygen isotope variability in free-swimming organisms
}

\author{
Benjamin J. Linzmeier ${ }^{1}$
}

Received: 31 August 2018/Accepted: 14 February 2019/Published online: 28 March 2019

(C) Akademie der Naturwissenschaften Schweiz (SCNAT) 2019

\begin{abstract}
Serially sampled oxygen isotope ratios $\left(\delta^{18} \mathrm{O}\right)$ from fossil and modern cephalopods may provide new insight into the behavior and longevity of individuals. Interpretation of these data is generally more difficult than similar data from bivalves or brachiopods because the measured $\delta^{18} \mathrm{O}$ from shell combines both seasonal change and depth change over the life of an individual. In this paper, a simple null model is presented combining the three fundamental controls on a measured $\delta^{18} \mathrm{O}$ profile in a free-swimming organism: swimming behavior, seasonal water column change, and time averaging in sampling. Model results indicate that seasonal variability in $\delta^{18} \mathrm{O}$ in a free-swimming organism can be interpreted in locations with strong seasonality through most of the swimming range but is complicated by swimming velocity and is sometimes best expressed by changes in $\delta^{18} \mathrm{O}$ variance rather than simple sinusoidal patterns. In other locations with a stable thermocline or seasonal ranges in only a small portion of the water column, no variability caused by seasonality would be expected. Furthermore, large ranges of $\delta^{18} \mathrm{O}(\sim 4 \%)$ are possible within and between individuals in settings with persistent thermoclines like the tropics, depending on the swimming depth limits and behavior of individuals. These results suggest that future interpretation of serially sampled $\delta^{18} \mathrm{O}$ should consider seasonal water column variation from either modern or modeling sources in addition to comparison to co-occurring benthic and planktonic organisms. Additionally, this modeling casts doubt on the promise of isotope sclerochronology alone as a growth chronometer in ammonites and other freeswimming fossil organisms and highlights the need for other methods of quantitatively determining age.
\end{abstract}

Keywords Modeling $\cdot$ Stable isotopes $\cdot$ Sclerochronology $\cdot$ Seasonality $\cdot$ Growth rates

\section{Introduction}

The field of sclerochronology has provided important insight into paleoclimate (Jones 1983; Schöne et al. 2011) and evolution (Ivany et al. 2000; Moss et al. 2017). Sclerochronological study involves serially sampling isotope or trace element ratios from accretionary grown skeletal parts in the context of growth banding. Commonly, the $\delta^{18} \mathrm{O}$

Editorial Handling: K. Ritterbush.

Electronic supplementary material The online version of this article (doi:https://doi.org/10.1007/s13358-019-00187-3) contains supplementary material, which is available to authorized users.

Benjamin J. Linzmeier

benL@earth.northwestern.edu

1 Department of Earth and Planetary Science, Northwestern University, Evanston, IL, USA signal in bivalve mollusks is used in interpretation of seasonality caused by changing temperature and can therefore be a growth chronometer because one complete sinusoid can be equated to 1 year of growth [e.g. Moss et al. 2017; Judd et al. 2018]. This interpretation is possible in bivalves because they are effectively sessile in a small area of seafloor and are therefore can function as fixed recorders of environmental conditions. In any long-lived (1 year or more) free swimming organism, environmental conditions recorded in the geochemistry of the shell encompass variation due to movement through an environment as well as seasonal variation in those conditions. Analyses of $\delta^{18} \mathrm{O}$ in marine fish otoliths, for instance, are commonly interpreted as only reflecting ontogenetic habitat change across a thermal gradient and do not record seasonality (Gerringer et al. 2018; Helser et al. 2018). Lacustrine otolith $\delta^{18} \mathrm{O}$, however, is sometimes interpreted to indicate seasonal temperature changes due to strong seasonal variation in lake temperature (Weidel et al. 2007). 
Workers doing sclerochronology of cephalopods by interpreting $\delta^{18} \mathrm{O}$ variability in particular have generally either favored the influence of movement through environments (Landman et al. 1983, 1994; Rexfort and Mutterlose 2006; Lukeneder et al. 2008, 2010; Lukeneder 2015; Linzmeier et al. 2016, 2018) or seasonality (Fatherree et al. 1998; Zakharov et al. 2005, 2011; Lécuyer and Bucher 2006; Dutton et al. 2007; Ellis and Tobin 2019). Because an independent chronometer in the shell has not been identified to determine annual growth rate due to the ambiguity of surficial growth banding (Doguzhaeva 1982; Landman 1983; Bucher et al. 1996), it has been impossible to conclusively test between the two interpretations in deep time. Additionally, heretofore, no model exists to incorporate the influence of both location and seasonality on potentially recorded patterns of $\delta^{18} \mathrm{O}$ variability in the shells of free swimming cephalopods or freeswimming organisms more generally, and because of this, comparisons with sea surface temperature variability have commonly been done in fossils (Lécuyer and Bucher 2006; Dutton et al. 2007) and occasionally in modern material (Liu et al. 2011).

Modern oceanographic research has provided abundant data on the thermal profiles in the modern ocean [Fig. 1, Locarnini et al. 2013]. These capture temperature change with depth as well as seasonal temperature changes at each depth (Figs. 1, 2). Because cephalopod shell appears to precipitate in oxygen isotope equilibrium with seawater (Tourtelot and Rye 1969; Landman et al. 1994), the temperature data from the World Ocean Atlas can be used to predict what $\delta^{18} \mathrm{O}$ shell would be precipitated as an individual was passing through a depth. To predict $\delta^{18} \mathrm{O}$ of aragonite $\left(\delta^{18} \mathrm{O}_{\text {aragonite }}\right)$ in this paper, the temperature equation for inorganic aragonite precipitation calibrated by Kim et al. (2007) is used because it has been calibrated across a wide range of temperatures $\left(0-40{ }^{\circ} \mathrm{C}\right)$. This

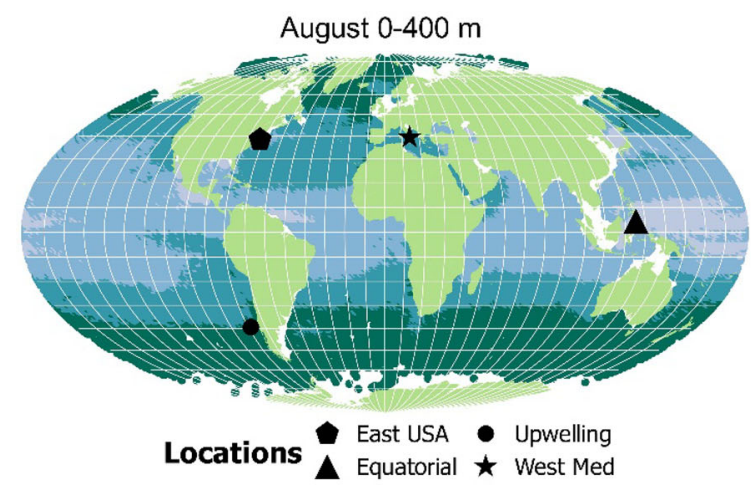

Fig. 1 Maps showing expected $\delta^{18} \mathrm{O}_{\text {aragonite }}$ range caused only by temperature between the surface and $400 \mathrm{~m}$ depth in the global ocean. Locations for thermocline data used in simulation are indicated by different shapes. White areas near continents are shelves where the seafloor is shallower than $400 \mathrm{~m}$. a Water column structure for calibration is within statistical error of the commonly used formula based on biogenic aragonite (Grossman and $\mathrm{Ku}$ 1986). The equation is as follows:

$$
\begin{aligned}
1000 \ln \alpha_{\text {aragonite-water }}= & 17.88 \pm 0.13\left(\frac{10^{3}}{T}\right)-31.14 \\
& \pm 0.46,
\end{aligned}
$$

where temperature $(\mathrm{T})$ is in $\mathrm{K}$. The $1000 \ln \alpha_{\text {aragonite-water }}$ notation is nearly equivalent to $\delta^{18} \mathrm{O}_{\text {aragonite }}-\delta^{18} \mathrm{O}_{\text {water }}$ across the range of calculations done in this paper. The $\delta^{18} \mathrm{O}$ of ocean water changes with evaporation and precipitation at the surface as well as thermohaline circulation patterns (LeGrande and Schmidt 2006). Because this change $(+1 \%$ vertical change across the top $250 \mathrm{~m}$ in the Tropical Atlantic) is small relative to the influence expected for temperature (4-6\%) in the depth ranges modeled here, it is currently not implemented (Fig. 1).

Precise swimming behavior and speed of extinct cephalopods is an outstanding area of inquiry and has implications for energetics cephalopod-rich ecosystems (Naglik et al. 2015). Debate has continued around the swimming potential of ammonites in particular because soft tissue preservation is likely not favored (Clements et al. 2017). Extensive work has been done to quantify maximal swimming velocities based on shell morphologies (e.g. Chamberlain and Westermann 1976; Jacobs 1992; Chamberlain 1993; Jacobs and Chamberlain 1996; Lemanis et al. 2015), but telemetry studies of Sepia (Aitken 2001), Loligo (O'Dor et al. 2002), Illex (Nakamura 1993), and Nautilus (O'Dor et al. 1993) suggest sustained swimming velocities are far below maximal velocities and also below predicted optimal swimming velocities (O'Dor 2002). Maximum swimming velocities in many planispiral ammonites were likely to be $<10 \mathrm{~cm} / \mathrm{s}$ (Jacobs 1992). Slower sustained swimming velocities are therefore more reasonable to model; however, a suite of values can be

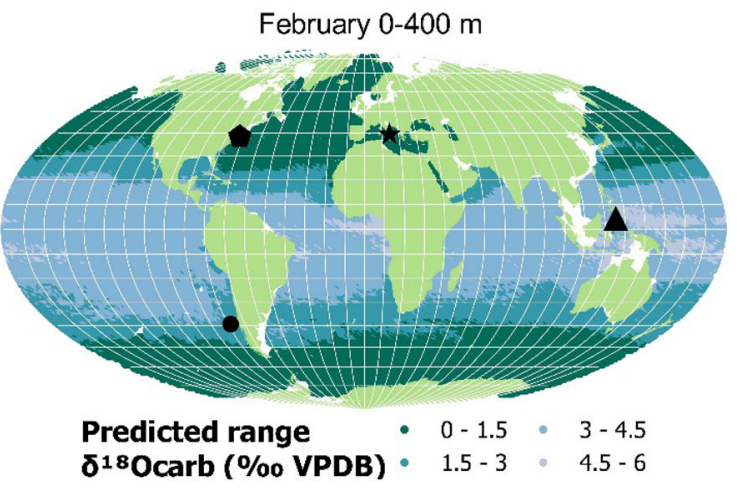

August, displaying near-peak northern hemisphere summer temperatures. b Water column structure for February, displaying nearminimum northern hemisphere winter temperatures. The spatially extensive influence of seasonality in the mid-Latitudes is most apparent in the North Atlantic. Data from (Locarnini et al. 2013) 


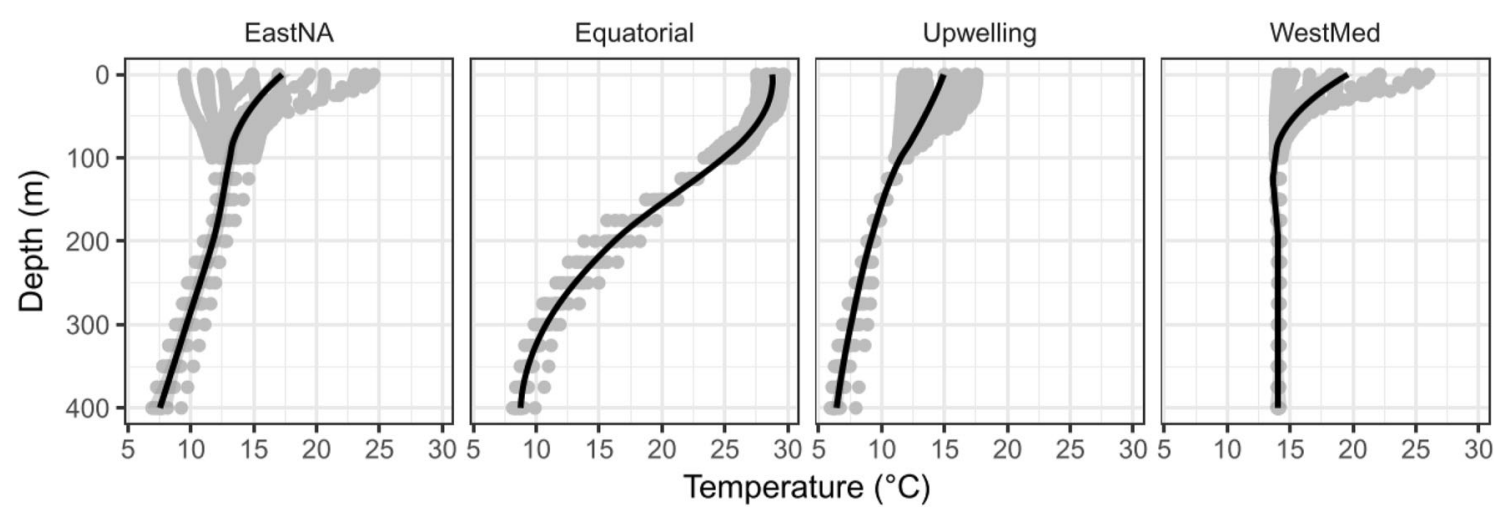

Fig. 2 Temperature with depth at the four modeled locations from Fig. 1. Each individual gray point is a monthly average temperature at that depth in that location from (Locarnini et al. 2013). Black lines summarize average annual thermocline shape at each location. Note that the locations EastNA, WestMed, and Upwelling have large

used. Furthermore, the vertical swimming velocity component is most important to consider in this model because the $\delta^{18} \mathrm{O}_{\text {aragonite }}$ is controlled by temperature that covaries with depth and is likely smaller than any other velocity in ammonites (Westermann 1996).

This paper provides a null hypothesis for oxygen isotope variability within the shells of free-swimming organisms based on swimming speed, time averaging, and thermal stratification from a variety of locations. The model presented is general and can be applied in both modern and ancient settings when coupled to global or regional climate model results. These simulations suggest that with better constraints on growth rate and potential swimming velocities, water column structure could be determined from serially sampled data of free swimming organisms.

\section{Methods}

A simple model (SeasMigratR) was constructed in three parts to simulate both the natural variability in the $\delta^{18-}$ $\mathrm{O}_{\text {aragonite }}$ of free-swimming, continuously accreting organism and the effects of time averaging due to inherent limits of necessary sample volumes. The model has been written in the $\mathrm{R}$ programming language ( $\mathrm{R}$ Core Team 2014) and divided into three complimentary functions that are included as supplemental information with this publication. Simplified natural, environmentally induced $\delta^{18} \mathrm{O}$ variability is achieved through linear interpolation of temperatures at each meter of water depth each day across an entire year (Fig. 2) using data from the World Ocean Atlas (Locarnini et al. 2013). Calculation of $\delta^{18} \mathrm{O}$ at each depth is done with Eq. 1 (Kim et al. 2007) assuming $\delta^{18-}$ $\mathrm{O}_{\text {water }}$ is uniform and 0\% (VSMOW, Vienna Standard annual temperature variability in the upper $100 \mathrm{~m}$ of the water column. Additionally, the EastNA water column has a mid-depth temperature high during some portions of the year (left-most points in the figure)

Mean Ocean Water). Locations used for model results presented in this paper are shown in Fig. 1.

The behavioral component is achieved through a depthchange per hour function. Although other behaviors are potentially modeled, in this paper behavior is implemented as a bound random walk where the hour-to-hour variation is approximated as a normal distribution of vertical velocities with the first standard deviation of velocity set by the velocity inputs listed in the figures. The bounds of the walk are set independently and in the cases modeled below are the surface $(0 \mathrm{~m})$ and $400 \mathrm{~m}$ water depth. The initial depth is drawn randomly from a uniform distribution between the bounds. If a walk reaches a bound, it must stay between bounds but can continue next to the bound for multiple time-steps. The maximum velocities (1 SD) approximate modern tracking of Nautilus in the wild $0.027 \mathrm{~m} / \mathrm{s}$ (Carlson et al. 1984; Ward et al. 1984; O’Dor et al. 1993; Dunstan et al. 2011). Minimum velocities are below that of $0.0013 \mathrm{~m} / \mathrm{s}$, a slow jetting velocity calculated for hatchling ammonites (Lemanis et al. 2015). Velocity inputs in the model runs shown here are in meters per hour and range from 5 to $100 \mathrm{~m} / \mathrm{h}$.

The time averaging of the model has two components, one is the distance or time averaged by a single analysis, and the other is a random 'rejection' column created from a uniform distribution with a defined probability of rejection. This rejection flag can be thought of as randomly distributed cracks of alteration or a rejected analysis due to quality control during assessment of mass spectrometry results. This component is not used for the comparison of expected patterns in bulk isotope analyses (Figs. 3, 4, 5, 6, 7). A fixed growth rate of $35 \mu \mathrm{m} /$ day with a time averaging of $250 \mu \mathrm{m}$ of growth is used (Fig. 3) and approximates both the rate of growth of modern Nautilus and time averaging of bulk samples (Auclair et al. 2004; Linzmeier 


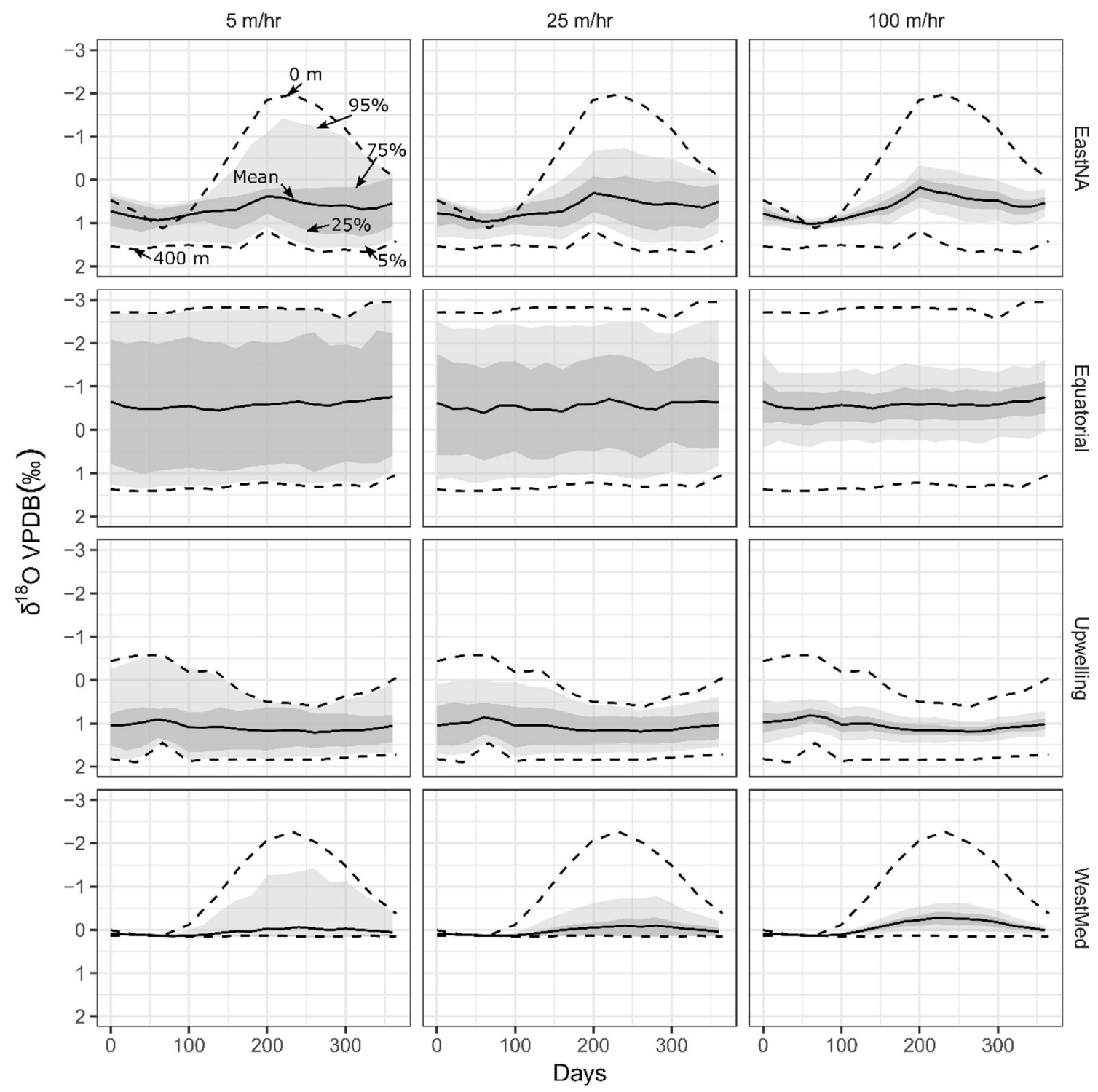

Fig. 3 Model $\delta^{18} \mathrm{O}_{\text {aragonite }}$ results for 500 simulations of swimming at four distinct locations with three different swimming velocities with a uniform time averaging and growth rate. Solid black lines show the average trajectory for model results. Most lines are nearly horizontal. Dashed bounding lines are the surface $(0 \mathrm{~m})$ and deep-water $(400 \mathrm{~m})$ temperatures from the World Ocean Atlas (Locarnini et al. 2013) converted to $\delta^{18} \mathrm{O}_{\text {aragonite }}$ using Eq. 1 . The apparent mismatch in the early part of the year from EastNA is due to the maximum temperature being near $100 \mathrm{~m}$ depth during part of the year

et al. 2016). Ammonite age at maturity is thought to range from 1 to 7 years, and growth rate likely varies through time (Bucher et al. 1996), so these fixed rates of growth based on Nautilus are only for consistency. Two more fixed time averaging of $70 \mu \mathrm{m}$ and $800 \mu \mathrm{m}$ of growth is used (Fig. 4) to test the sensitivity of the model to growth rate. Serially sampled bulk individuals from the published literature are compared to the $35 \mu \mathrm{m} /$ day and the averaging of $250 \mu \mathrm{m}$ growth (equivalent to bulk sampling) from modern locations of similar latitude (Fig. 6).
(Fig. 2). Dark gray bands bound the 25th-75th percentiles of model results. Lighter gray bands bound the 5 th -95 th percentiles. Sinusoidal $\delta^{18} \mathrm{O}$ variability resolvable beyond typical instrumental precision ( $\pm 0.1 \%$ 2SD) would not be unambiguously detected in slow swimmers from many locations but could potentially be detected in fast swimmers at mid- or high-latitude locations where strong seasonal controls of temperature structure of the water column are present

\section{Results}

\section{Sensitivity to swimming speed and location}

Mean

The modeled water column location (Fig. 1) and therefore water temperature (Fig. 2) has the strongest control on the $\delta^{18} \mathrm{O}_{\text {aragonite }}$ results of this model. Mean $\delta^{18} \mathrm{O}_{\text {aragonite }}$ is not 


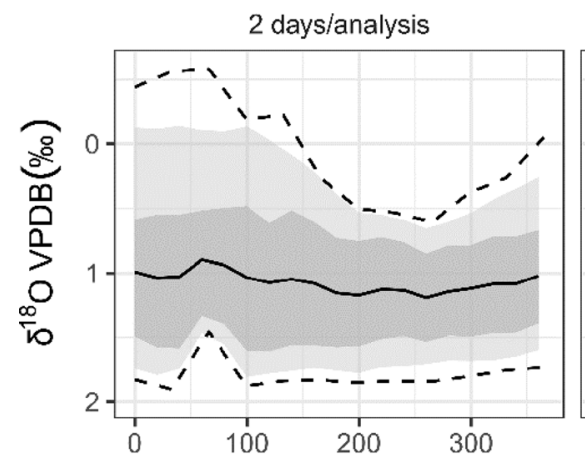

Fig. 4 Model $\delta^{18} \mathrm{O}_{\text {aragonite }}$ results for 500 simulations a fixed growth rate and swimming velocity with three time-averaging treatments for the Upwelling location. The black line is the mean value for all model runs. Dark gray band delimitation of 25 th and 75 th percentiles. Light gray bands are the 5th and 95th percentiles. Increased time averaging

found to change within environments across swimming velocities $(<0.1 \%$, Table 1$)$.

\section{Variability}

As swimming velocity changes from the slowest modeled value $(5 \mathrm{~m} / \mathrm{h})$ to the highest $(100 \mathrm{~m} / \mathrm{h})$, expected variability (summarized as 1 standard deviation, Table 1) in $\delta^{18-}$

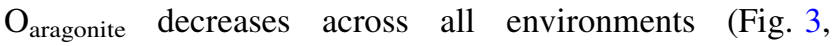
Table 1). The largest reduction is in the equatorial environment with a well-developed thermocline and minimal seasonal temperature change (Figs. 2, 3, Table 1). The smallest change is observed in the WestMed environment with a uniform water column temperature below $100 \mathrm{~m}$ (Figs. 2, 3, Table 1).

\section{Skew}

Skew of the distribution was also found to vary with swimming speed across environments with faster swimmers having a smaller magnitude of skew. Overall, the magnitude of skew is largest in the Mediterranean environment and smallest in the equatorial environment (Table 1).

\section{Range}

The expected range of $\delta^{18} \mathrm{O}_{\text {aragonite }}$ also changes with swimming velocity but is also strongly controlled by the thermal characteristics of the water column at specific locations (Fig. 3, Table 1). Faster swimmers are generally expected to have smaller ranges in the measured $\delta^{18} \mathrm{O}_{\text {arag- }}$ onite across all environments (Fig. 3, Table 1).

\section{Sensitivity to time averaging}

When the model is run to average less time per sample, the variability and range of the faster swimming model output increases across all environments (Fig. 4, Table 2). The $25 \mathrm{~m} / \mathrm{h}$ model (Fig. 4) has similar characteristics to the $5 \mathrm{~m} / \mathrm{h}$ model (Fig. 3, Table 1) when time averaging is decreased. Increased time averaging reduces the variability produced by the model (Fig. 4). Mean values and data skew do not change with time averaging (Table 2).

\section{Sensitivity to depth limits}

When the model is run keeping swimming velocity and time averaging constant but increasing the depth limits for the model, the range and variability increases and the sinusoidal character of the mean through the year decreases (Fig. 5, Table 3). Skewness of the distributions increases as the depth limit increases, and the expected range of $\delta^{18} \mathrm{O}$ also increases (Table 3).

\section{Discussion}

\section{Model assumptions}

Four major assumptions underpin the implementation of this model and should therefore be examined in greater detail.

(1) Growth is modeled as continuous and uniform. In living organisms, continuous, invariant growth rates are unlikely to occur. The growth rate of bivalves often varies with temperature and is fastest in a window of optimum temperature [e.g. Judd et al. 2018]. In cephalopods, statolith growth rate is 

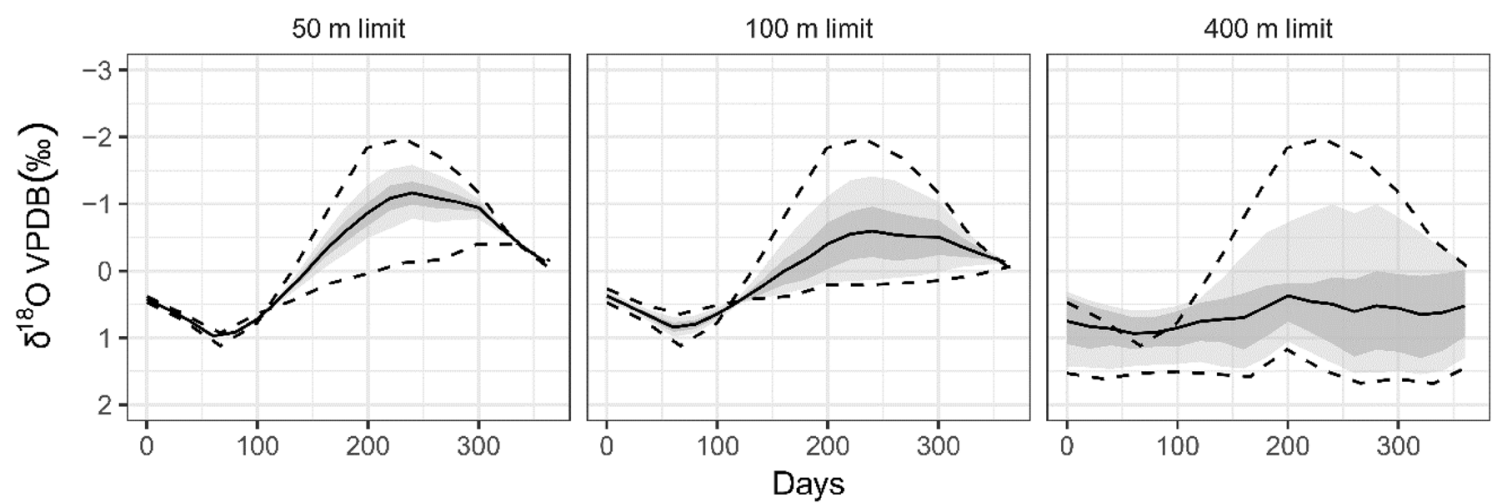

Fig. 5 Model $\delta^{18} \mathrm{O}_{\text {aragonite }}$ results for 500 simulations with a fixed growth rate, time averaging, and swimming speed of $10 \mathrm{~m} / \mathrm{h}$ for different depth limits at the Eastern North American location. As the

depth limit shallows, the expected variability in $\delta^{18} \mathrm{O}$ decreases and the mean pattern is more sinusoidal
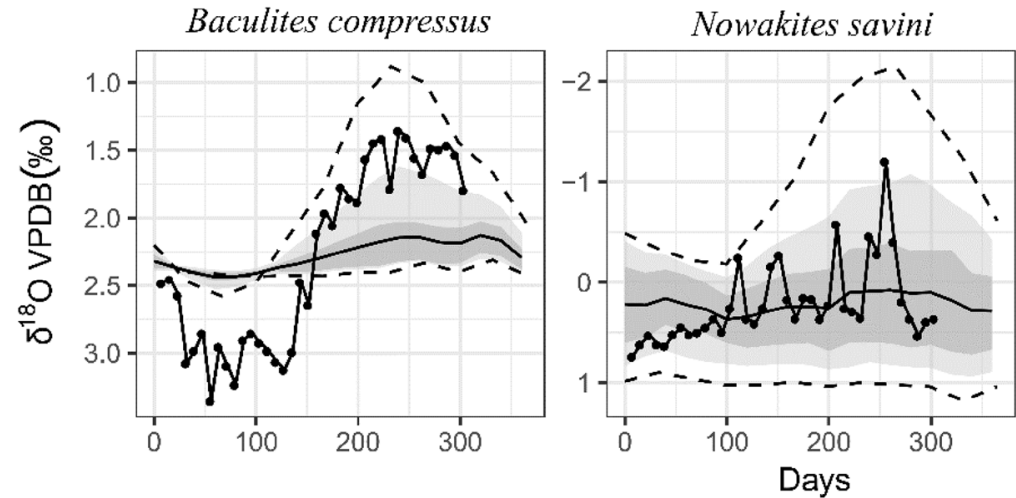

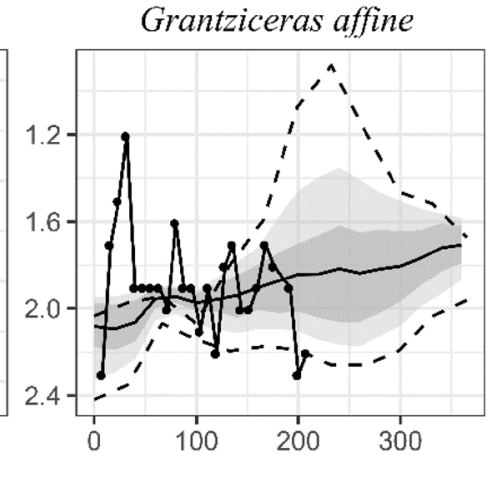

Fig. 6 Serially sampled $\delta^{18} \mathrm{O}_{\text {aragonite }}$ for previously published ammonites overlain on predicted $\delta^{18} \mathrm{O}_{\text {aragonite }}$ variability due solely to temperature at different locations, $25 \mathrm{~m} / \mathrm{h}$ swimming speed, and 7 days time averaging per analysis. Published oxygen isotope values are adjusted to set the simulated mean and measured mean to be equal and points are published point order multiplied by 8 to scale to near
1 year. Baculites compressus (Fatherree et al. 1998) is overlain on the prediction derived from modern temperatures at $51.5 \mathrm{~N}, 170.5 \mathrm{~W}$. Nowakites savini (Lukeneder et al. 2010) is overlain on the prediction from 33.5 N, 170.5 W. Grantziceras affine (Zakharov et al. 2011) overlays $70.5 \mathrm{~N}, 15.5 \mathrm{E}$ influenced by both temperature and food availability (Zumholz et al. 2006; Aguiar et al. 2012). Growth in modern Nautilus macromphalus appears to be continuous across a wide range of temperatures, but daily rates vary (Linzmeier et al. 2016). Varying the amount of time averaging also indicates that faster growing individuals would have more variability than slower growing individuals with the same swimming velocity (Figs. 3, 4, Table 1). Variation in daily growth rate is unlikely to impact the model results because individual depth trajectory is random, and therefore individuals will not be at the same depth at the same time from day to day. Growth rate dramatically varying with temperature could influence these results but would likely cause reduced variability across all environments and swimming speeds.
(2) Continuous activity is possible. It is unlikely that any individual was swimming at these sustained velocities every hour throughout a whole year; however, the random walk is modeled as a normal distribution, so the average hourly vertical swimming velocity is zero. This approach, however, leaves periods of rest at depths and different modes of depth migration to discuss. Modern cuttlefish appear to have resting periods that may indicate sleep (Frank et al. 2012). Telemetry of modern Nautilus suggests that swimming can happen at any point in a day although it is often concentrated at dawn and dusk (Ward et al. 1984; Dunstan et al. 2011). Because time averaging in this model encompasses days to weeks of growth, any resting period of less than $50 \%$ of the time would be unlikely to influence the variance structure for a bound-random walk style depth migration. 
Table 1 Summary of modeled $\delta^{18} \mathrm{O}_{\text {aragonite }}$ data distributions for Fig. 3 at each location (Figs. 1,2) with different vertical swimming velocities

\begin{tabular}{lcccccc}
\hline Location & Vertical velocity $(\mathrm{m} / \mathrm{h})$ & Average $\delta^{18} \mathrm{O}(\%, \mathrm{VPDB})$ & $1 \mathrm{SD} \delta^{18} \mathrm{O}$ & Skewness $\delta^{18} \mathrm{O}$ & Lowest $\delta^{18} \mathrm{O}(\% 0, \mathrm{VPDB})$ & Highest $\delta^{18} \mathrm{O}(\%, \mathrm{VPDB})$ \\
\hline EastNA & 5 & 0.66 & 0.59 & -1.03 & -1.87 & 1.65 \\
& 25 & 0.66 & 0.50 & -0.78 & -1.36 & 1.58 \\
& 100 & 0.64 & 0.33 & -0.70 & -0.87 & 1.33 \\
Equatorial & 5 & -0.54 & 1.43 & -0.26 & -2.96 & 1.41 \\
& 25 & -0.56 & 1.17 & -0.15 & -2.85 & 1.36 \\
& 100 & -0.59 & 0.52 & -0.05 & -2.26 & 1.10 \\
Upwelling & 5 & 1.08 & 0.55 & -0.78 & -0.57 & 1.87 \\
& 25 & 1.07 & 0.45 & -0.47 & -0.41 & 1.84 \\
WestMed & 5 & 1.04 & 0.24 & -0.51 & -0.03 & 1.70 \\
& 25 & 0.06 & 0.28 & -4.05 & -2.11 & 0.18 \\
& 100 & 0.03 & 0.21 & -2.51 & -1.46 & 0.17 \\
\end{tabular}

Table 2 Summary of modeled $\delta^{18} \mathrm{O}_{\text {aragonite }}$ data distributions at each time averaging step (Fig. 4) with uniform vertical swimming velocity and at the upwelling location

\begin{tabular}{llllll}
\hline Time averaging (days/analysis) & Average $\delta^{18} \mathrm{O}(\%, \mathrm{VPDB})$ & $1 \mathrm{SD} \delta^{18} \mathrm{O}$ & Skewness $\delta^{18} \mathrm{O}$ & Lowest $\delta^{18} \mathrm{O}(\%$, VPDB $)$ & Highest $\delta^{18} \mathrm{O}(\%, \mathrm{VPDB})$ \\
\hline 2 & 1.07 & 0.51 & -0.56 & -0.49 & 1.86 \\
7 & 1.07 & 0.40 & -0.47 & -0.32 & 1.81 \\
23 & 1.07 & 0.26 & -0.40 & 0.09 & 1.73 \\
\hline
\end{tabular}

Table 3 Summary of modeled $\delta^{18} \mathrm{O}_{\text {aragonite }}$ data distributions at each depth limit step (Fig. 5) with uniform vertical swimming velocity and time averaging at the Eastern North American location

\begin{tabular}{lclccc}
\hline Depth limit $(\mathrm{m})$ & Average $\delta^{18} \mathrm{O}(\% \mathrm{v}, \mathrm{VPDB})$ & $1 \mathrm{SD} \delta^{18} \mathrm{O}$ & Skewness $\delta^{18} \mathrm{O}$ & Lowest $\delta^{18} \mathrm{O}(\% \mathrm{o}, \mathrm{VPDB})$ & $\mathrm{Highest} \delta^{18} \mathrm{O}(\% 0, \mathrm{VPDB})$ \\
\hline 50 & -0.18 & 0.75 & 0.04 & -1.80 & 1.03 \\
100 & 0.03 & 0.57 & -0.40 & -1.78 & 1.02 \\
400 & 0.67 & 0.57 & -0.86 & -1.80 & 1.64 \\
\hline
\end{tabular}

Additionally, unless resting occurs at a specific depth and time and is not done opportunistically in response to external stimuli, it is unlikely to influence these results and would instead make the faster swimming simulations look more like the slower swimming.

(3) Vertical swimming is possible. In modern Nautilus, depth change is coupled to along-bottom swimming in an environment with a steep forereef (Ward et al. 1984; Dunstan et al. 2011). If fossil groups were similarly constrained by a long-bottom swimming, both epeiric seaway and passive margin settings would greatly reduce the potential for depth change (Landman et al. 2018a). It is unknown, however, if fossil cephalopod groups were similarly constrained and vertical velocity components to many shell morphologies have been hypothesized (Westermann 1996).

(4) Shell $\delta^{18} \mathrm{O}_{\text {aragonite }}$ is driven by temperature rather than $\delta^{18} \mathrm{O}_{\text {water }}$ change. In much of the modern ocean, temperatures vary vertically by $5{ }^{\circ} \mathrm{C}$ within the top $100 \mathrm{~m}$. This condition was also potentially present to some extent for most of the Cretaceous (Huber et al. 2018). The $\delta^{18} \mathrm{O}_{\text {water }}$ of seawater varies by $\sim 4 \%$ across the surface ocean, with most of the difference being present in the Arctic Ocean and $~ 1 \%$ with depth (LeGrande and Schmidt 2006). The magnitude of the $\delta^{18} \mathrm{O}$ gradient expected in carbonates precipitated in $\delta^{18} \mathrm{O}$ equilibrium with water can have up to $25 \%$ attributed to the water composition rather than 
temperature component of the surface water. Further development of this model can explicitly test the influence of these assumptions on the modeled $\delta^{18} \mathrm{O}_{\text {aragonite variability using more advanced oceano- }}$ graphic data products.

\section{Broad patterns of variability and swimming velocity}

In locations with a strong, stable thermocline (e.g. Equatorial and Upwelling examples) $\delta^{18} \mathrm{O}_{\text {aragonite variability is }}$ large $(2-4 \%$ ) and continuous through the year. Variability approaches the surface-depth range in the modeled slow swimmers (Figs. 2, 3, 4). Faster swimmers, perhaps counterintuitively, would be expected to have reduced $\delta^{18} \mathrm{O}_{\text {aragonite }}$ variability across all environments given timeaveraged sampling (Figs. 3, 4). This reduced variability is caused by the more uniform sampling of the water column through the time-averaged sample. Similar expansion and reduction of variance is coupled to growth rates (Figs. 3, 4). In modern Nautilus, time-averaged $\delta^{18} \mathrm{O}_{\text {aragonite }}$ measurements have little variance over the lifetimes of individuals (Landman et al. 1994; Auclair et al. 2004; Zakharov et al. 2006) even though depth migration behavior has been documented by telemetry (Carlson et al. 1984; Ward et al. 1984; Dunstan et al. 2011) and high spatial resolution $\delta^{18} \mathrm{O}_{\text {aragonite }}$ by SIMS (Linzmeier et al. 2016).

In locations with a thermal profile that becomes nearly uniform in value seasonally, clustering of $\delta^{18} \mathrm{O}_{\text {aragonite }}$ variability is expected (Fig. 3, WestMed or EastNA). Samples from these locations would be most likely to produce sinusoidal variability in bulk sampling, but not all individuals from these locations would be expected to have sinusoidal variability present because individuals may swim to different depths at different times (Helser et al. 2018; Linzmeier et al. 2018). Instead of simple sinusoidal variability, individuals are expected to have clusters of higher or lower variability $\delta^{18} \mathrm{O}_{\text {aragonite. Therefore, if }}$ interpreting years of growth, years could be identified as the distance between the middle of high variance areas of the shell rather than local minima or maxima as is commonly done in bivalves (Ivany 2012).

\section{Reinterpretation of bulk data}

\section{Populations}

Potential variation within individuals and across populations is predicted by this modeling. For some locations and swimming speeds, large ranges in $\delta^{18} \mathrm{O}_{\text {aragonite }}(\sim 4 \%)$ are possible (Fig. 3). Individual serially sampled ammonites may have any trajectory within this modeled range. Recent serially sampled ammonites that lived in similar water column conditions show divergent patterns of $\delta^{18} \mathrm{O}$ (Landman et al. 2018b; Linzmeier et al. 2018) and recent otoliths show similar patterns (Helser et al. 2018). Population-scale sampling of multiple individuals would have individual-to-individual variability approaching that range as well, assuming that sampling is random with respect to time within each shell. This would mean for instance, if Sphenodiscus, Baculites, and Discoscaphites from the Owl Creek Formation (Maastrichtian, Mississippi, USA) had similar growth rates, Sphenodiscus would have had the fastest and Discoscaphites the slowest vertical swimming speeds based on interpretation of population-level variability (Sphenodiscus $0.75 \%$ o $1 \mathrm{SD} \quad N=8$ and Discoscaphites $0.24 \%$ o $1 \mathrm{SD} N=78$, Sessa et al. 2015). The skew of the distributions reported $(+0.3$ and +0.4$)$ was not reproduced from temperature alone but could potentially be due to freshwater influence coupled to temperature seasonality (Sessa et al. 2015). Other populations of Baculites also show similarly variable $\delta^{18} \mathrm{O}_{\text {aragonite }}$ although some are apparently coupled to methane seep ecosystems and preclude migration along the bottom and far from the seep (Landman et al. 2018b).

\section{Individuals}

Considering these model results, published records of $\delta^{18-}$ $\mathrm{O}_{\text {aragonite }}$ in ammonites can likely be reinterpreted to incorporate both seasonality and local thermocline conditions (Fig. 6). To do this reinterpretation, paleolatitudes for sample collection sites of three serially sampled ammonites (Baculites compressus, Nowakites savini, and Grantziceras affine, from (Fatherree et al. 1998; Lukeneder et al. 2010; Zakharov et al. 2011), respectively) were found using Gplates (Wright et al. 2013), modern representative locations near to those latitudes were picked from the World Ocean Atlas Dataset focusing on open-ocean data with complete annual coverage (Locarnini et al. 2013). For each representative location, a single swimming velocity $(25 \mathrm{~m} /$ h) and time averaging (7 days/analysis) were calculated. The entire measured individual datasets were scaled to fit within the window of a single year and the measured values were adjusted to have an equal mean $\delta^{18} \mathrm{O}_{\text {aragonite }}$ to simulated data.

The modeled context provides some additional insight into the interpretation of these data. The Baculites compressus (Campanian, Upper Cretaceous; Pierre Shale, South Dakota, USA, Fatherree et al. 1998) shows a partial sinusoid with greater variance than expected from temperatures alone (Fig. 6). Because the Western Interior Seaway is thought to be a very dynamic environment with freshwater input (Dennis et al. 2013; Petersen et al. 2016; 
Linzmeier et al. 2018) and seasonal thermal stratification (Kump and Slingerland 1999), it is possible the representative water column does not adequately capture this variation. Small amounts of variation in $\delta^{18} \mathrm{O}_{\text {water }}$ could explain the portion of the $\delta^{18} \mathrm{O}$ not explained by temperature (Dennis et al. 2013; Petersen et al. 2016). The Nowakites savini (Santonian, Upper Cretaceous; Edelbachgraben, Austria, Lukeneder et al. 2010) could be interpreted as a single year combining of swimming and seasonal modulation of swimming-induced variance rather than a strict ontogenetic habitat change (Fig. 6). The Grantziceras affine (Albian, Lower Cretaceous; Matanuska River Basin, Alaska, USA, Zakharov et al. 2011) may not show any annual variability in $\delta^{18} \mathrm{O}$ and could just show behavior of this individual during a portion of the year (Fig. 6).

\section{Nautilus}

These model results also help to explain why in Nautilus, a known depth migrator, $\delta^{18} \mathrm{O}$ variance from bulk samples is low (Taylor and Ward 1983; Landman et al. 1994; Moriya et al. 2003; Auclair et al. 2004; Ohno et al. 2015). Comparison of the slowly precipitating septa (Westermann et al. 2004) to shell wall that grows much faster (Martin et al. 1978) has recently been interpreted as a depth bias of septal growth (Moriya 2015) or disequilibrium precipitation of septa (Ohno et al. 2015). Perhaps the time-averaging difference between samples, as modeled here, could explain this difference (Fig. 4). Higher temporal resolution sampling of the outer shell wall of Nautilus macromphalus reveals a larger amount of variability in $\delta^{18} \mathrm{O}_{\text {aragonite }}$ (Linzmeier et al. 2016) compared to traditional bulk sampling (Auclair et al. 2004). Higher spatial sampling of the septa also reveals $\delta^{18} \mathrm{O}$ variability that bulk analysis does not (Oba et al. 1992).

\section{Future model development}

This preliminary model simplifies both the complicated nature of coastal oceanography (Sobarzo et al. 2007; van Leeuwen et al. 2015) and potential behavioral differences between groups based on location (Ward et al. 1984; Dunstan et al. 2011). Future development will correct these simplifications to provide better quantitative constraints on the expected $\delta^{18} \mathrm{O}$ variability within individuals and populations of free-swimming fossil groups. Additionally, because the biological pump creates a gradient in $\delta^{13} \mathrm{C}$ across the depths of interest (Hain et al. 2014) incorporation of this phenomena into the model would be useful, although the contribution of respired carbon may be variable as an organism swims (McConnaughey and Gillikin 2008; Landman et al. 2018b). Application of inverse methods (e.g. Passey et al. 2005; Sakamoto et al. 2018) on these data may provide additional insight into growth rates, behaviors, and palaeoceanographic conditions including water column seasonality. Irrespective of the direction future modeling takes, it is clear that additional large stable isotope datasets from modern and fossil populations and individuals will be necessary for testing future model development.

\section{Determining growth rates in fossil cephalopods}

This modeling suggests that when attempting sclerochronological growth rate determination in fossil cephalopods, both morphological characteristics and environmental characteristics will be important for sample selection and data interpretation. In modern ocean, higher latitude locations on the Western continental margins have stronger seasonal variation throughout the water column when compared to low latitude locations (Figs. 1, 2). Additionally, locations adjacent to seasonally varying ocean currents (e.g. Gulf Stream) may have strong seasonal signals (Figs. 1, 2). The broad distribution of these characteristics that affects seasonality can be assessed with comparison to paleogeographic reconstructions (Scotese 1991; Wright et al. 2013). Ammonites that are likely slower swimmers (e.g. serpenticones) from middle latitudes may contain clusters of $\delta^{18} \mathrm{O}$ variance caused by seasonally variable water column rather than simple sinusoids (Fig. 3). If potentially faster swimmers (e.g. oxycones) lived in locations with strong seasonal variation throughout the water column, sinusoidal variability may be expected. Groups confined to the shallowest water due to implosion (Hewitt 2000) may also show variability (Fig. 5). Growth rate estimates using isotope sclerochronology will require serially sampling multiple individuals (Ellis and Tobin 2019) from the same location if possible (Landman et al. 2018b). These methods must also be coupled with calculations derived from chamber evacuation (Bucher et al. 1996; Lukeneder 2015) and comparison to shell internal growth banding (Barbin 2013) analyzed with robust time series analysis methods (Meyers et al. 2001; Meyers 2014). Comparison of ammonites to cooccurring obligate benthic mollusks will provide a minimum estimate for expected seasonal $\delta^{18} \mathrm{O}$ variation within ammonites and provide insight into the potential of swimming behavior or migrations.

\section{Conclusions}

Expected patterns of shell $\delta^{18} \mathrm{O}$ within individual freeswimming organisms such as ammonites is complicated to interpret because of the combined effects of the thermocline, swimming speeds, and growth rate (Fig. 7). Quantitative and predictive frameworks based on modern, 


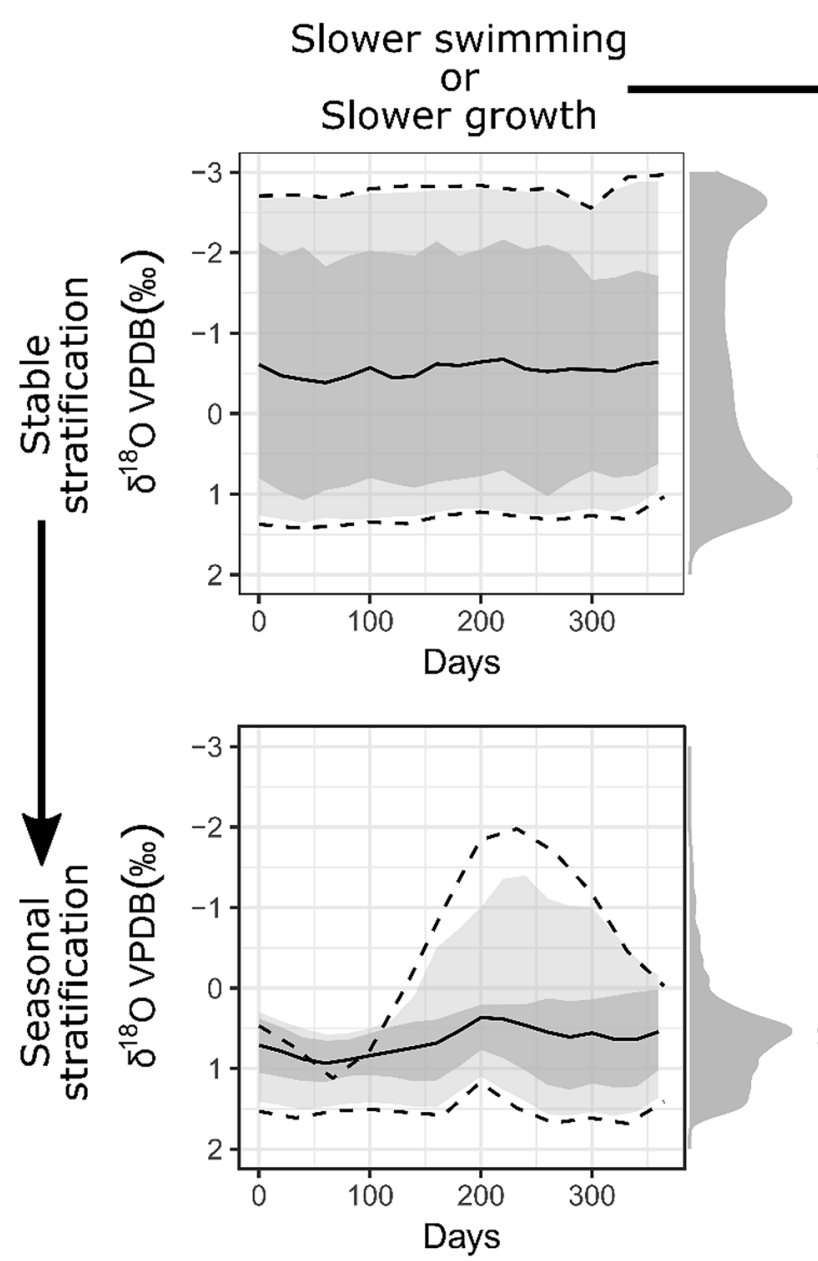

Fig. 7 Summary of the effects of growth rate, swimming speed, and seasonal stratification on $\delta^{18} \mathrm{O}_{\text {arg }}$ variability in free swimming organisms. Each panel has a summary kernel density plot on the right axis to illustrate the total distribution of $\delta^{18} \mathrm{O}_{\text {aragonite }}$ in each modeled field and represents the expectation for a population-level

distribution where serial sampling was not done. With increasing swimming speed or faster growth rate, $\delta^{18} \mathrm{O}_{\text {arg }}$ variability is expected to decrease (right panels). Seasonal water column variability is expected to skew $\delta^{18} \mathrm{O}_{\text {arg }}$ toward more positive values with occasional low values (bottom panels)

climate model, or comparative isotope analyses are necessary to disentangle the various conditions that influence any geochemical system that varies on timescales comparable to growth rates. It is clear that $\delta^{18} \mathrm{O}_{\text {aragonite }}$ variability is expected to be higher than instrumental precision for bulk analyses across many environments and therefore individuals may show unique trajectories through ontogeny, and reproducibility between individuals is not necessarily expected (Fig. 7). Variability measured in existing datasets reinterpreted in this quantitative framework and suggests similar vertical swimming velocities or different growth rates in some instances between co-occurring ammonites. Analysis of poorly streamlined ammonites (e.g. serpenticones) from locations that are likely to have strong seasonality may provide evidence for ammonite growth rates and water column structure. Future development of this model and more extensive $\delta^{18} \mathrm{O}$ sampling of ammonite material may yet disentangle growth rates and swimming behavior of the ammonites, but interpretation of bulk sampling alone may still be ambiguous and therefore more high temporal resolution sampling by SIMS may be required to use $\delta^{18} \mathrm{O}_{\text {aragonite }}$ records from ammonites to understand either habitat change or growth rates.

Acknowledgements I would like to thank G.L. Wolfe, R. Hoffmann, S.E. Peters, J.L. Schnell, B.B. Sageman, and A.C. Denny for discussion of this project and the model. I am also indebted to Neil Landman and Alexander Lukeneder for their thoughtful reviews of this manuscript. This project was partially supported by the University of Wisconsin-Madison Department of Geoscience through teaching assistantships and by a postdoctoral fellowship through the Ubben fund at Northwestern University. The code for this model is available as a supplemental file. 


\section{References}

Aitken, J. P. (2001). The bioenergetics of the giant Australian cuttlefish Sepia apama. PhD Thesis, MSc Thesis. (Dalhousie University: Halifax, Nova Scotia, Canada).

Auclair, A.-C., Lecuyer, C., Bucher, H., \& Sheppard, S. M. (2004). Carbon and oxygen isotope composition of Nautilus macromphalus: a record of thermocline waters off New Caledonia. Chemical Geology, 207, 91-100.

Barbin, V. (2013). Application of cathodoluminescence microscopy to recent and past biological materials: a decade of progress. Mineralogy and Petrology, 107, 353-362.

Bucher, H., Landman, N. H., Klofak, S. M., \& Guex, J. (1996). Mode and rate of growth in ammonoids; p. In N. H. Landman, K. Tanabe, \& R. A. Davis (Eds.), Ammonoid paleobiology (Vol. 13, pp. 407-461). Topics in Geobiology. New York: Plenum Press.

Carlson, B., McKibben, J. N., \& deGruy, M. V. (1984). Telemetric investigation of vertical migration of Nautilus belauensis in Palau. Pacific Science, 38, 183-188.

Chamberlain, J. A., Jr. (1993). Locomotion in ancient seas: Constraint and opportunity in cephalopod adaptive design. Geobios, 26, 49-61.

Chamberlain, J. A., Jr., \& Westermann, G. E. G. (1976). Hydrodynamic properties of cephalopod shell ornament. Paleobiology, 2, 316-331.

Clements, T., Colleary, C., De Baets, K., \& Vinther, J. (2017). Buoyancy mechanisms limit preservation of coleoid cephalopod soft tissues in Mesozoic Lagerstätten. Palaeontology, 60, 1-14.

R Core Team. (2014). R: A language and environment for statistical computing. Vienna: R Foundation for Statistical Computing.

de Aguiar, D. C., Rossi-Wongtschowski, C. L. D. B., \& Perez, J. A. A. (2012). Validation of daily growth increments of statoliths of Brazilian squid Doryteuthis plei and D. sanpaulensis (Cephalopoda: loliginidae). Bioikos, 26, 13-21.

Dennis, K. J., Cochran, J. K., Landman, N. H., \& Schrag, D. P. (2013). The climate of the Late Cretaceous: New insights from the application of the carbonate clumped isotope thermometer to Western Interior Seaway macrofossil. Earth and Planetary Science Letters, 362, 51-65.

Doguzhaeva, L. (1982). Rhythms of ammonoid shell secretion. Lethaia, 15, 385-394.

Dunstan, A. J., Ward, P. D., \& Marshall, N. J. (2011). Vertical distribution and migration patterns of Nautilus pompilius. PLoS ONE, 6, e16311.

Dutton, A., Huber, B. T., Lohmann, K. C., \& Zinsmeister, W. J. (2007). High-resolution stable isotope profiles of a dimitobelid belemnite: Implications for paleodepth habitat and Late Maastrichtian climate seasonality. Palaios, 22, 642-650.

Ellis, N. M., \& Tobin, T. S. (2019). Evidence for seasonal variation in $\delta^{13} \mathrm{C}$ and $\delta^{18} \mathrm{O}$ profiles of Baculites and implications for growth rate. Palaeontology, 1-16.

Fatherree, J. W., Harries, P. J., \& Quinn, T. M. (1998). Oxygen and carbon isotopic "dissection" of Baculites compressus (Mollusca: Cephalopoda) from the Pierre Shale (upper Campanian) of South Dakota; implications for paleoenvironmental reconstructions. Palaios, 13, 376-385.

Frank, M. G., Waldrop, R. H., Dumoulin, M., Aton, S., \& Boal, J. G. (2012). A preliminary analysis of sleep-like states in the cuttlefish Sepia officinalis. PLoS One, 7, e38125.

Gerringer, M. E., Andrews, A. H., Huss, G. R., Nagashima, K., Popp, B. N., Linley, T. D., et al. (2018). Life history of abyssal and hadal fishes from otolith growth zones and oxygen isotopic compositions. Deep Sea Research Part I: Oceanographic Research Papers, 132, 37-50.
Grossman, E. L., \& Ku, T.-L. (1986). Oxygen and carbon isotope fractionation in biogenic aragonite: Temperature effects. Chemical Geology: Isotope Geoscience Section, 59, 59-74.

Hain, M. P., Sigman, D. M., \& Haug, G. H. (2014). 8.18-The biological pump in the past; p. In H. D. Holland \& K. K. Turekian (Eds.), Treatise on Geochemistry (Vol. 2, pp. 485-517). Oxford: Elsevier.

Helser, T., Kastelle, C., Crowell, A., Ushikubo, T., Orland, I. J., Kozdon, R., et al. (2018). A 200-year archaeozoological record of Pacific cod (Gadus macrocephalus) life history as revealed through ion microprobe oxygen isotope ratios in otoliths. Journal of Archaeological Science: Reports, 21, 1236-1246.

Hewitt, R. A. (2000). Geological interpretations from cephalopod habitat and implosion depth limits. Revue de Paléobiologie, Special, 8, 95-107.

Huber, B. T., MacLeod, K. G., Watkins, D. K., \& Coffin, M. F. (2018). The rise and fall of the Cretaceous Hot Greenhouse climate. Global and Planetary Change, 167, 1-23.

Ivany, L. C. (2012). Reconstructing paleoseasonality from accretionary skeletal carbonates-Challenges and opportunities. In L. C. Ivany \& B. T. Huber (Eds.) Earth's Deep-Time Climate-The State of the Art in 2012. The Paleontological Society Papers (vol. 18, pp. 133-165). The Paleontological Society.

Ivany, L. C., Patterson, W. P., \& Lohmann, K. C. (2000). Cooler winters as a possible cause of mass extinctions at the Eocene/ Oligocene boundary. Nature, 407, 887-890.

Jacobs, D. K. (1992). Shape, drag, and power in ammonoid swimming. Paleobiology, 18, 203-220.

Jacobs, D. K., \& Chamberlain, J. A. (1996). Buoyancy and hydrodynamics in ammonoids; p. In N. H. Landman, K. Tanabe, \& R. A. Davis (Eds.), Ammonoid paleobiology (Vol. 13, pp. 169-224). Topics in Geobiology. New York: Plenum Press.

Jones, D. S. (1983). Sclerochronology: reading the record of the molluscan shell. American Scientist, 71, 384-391.

Judd, E. J., Wilkinson, B. H., \& Ivany, L. C. (2018). The life and time of clams: Derivation of intra-annual growth rates from highresolution oxygen isotope profiles. Palaeogeography, Palaeoclimatology, Palaeoecology, 490, 70-83.

Kim, S.-T., O’Neil, J. R., Hillaire-Marcel, C., \& Mucci, A. (2007). Oxygen isotope fractionation between synthetic aragonite and water: influence of temperature and $\mathrm{Mg}^{2+}$ concentration. Geochimica et Cosmochimica Acta, 71, 4704-4715.

Kump, L. R., \& R. L. Slingerland. (1999). Circulation and stratification of the early Turonian Western Interior Seaway: Sensitivity to a variety of forcings. In E. Barrera \& C. C. Johnson (Eds.) Evolution of the Cretaceous ocean-climate system (pp. 181-190). Geological Society of America Special Paper.

Landman, N. H. (1983). Ammonoid growth rhythms. Lethaia, 16, 248-248.

Landman, N. H., Cochran, J. K., Rye, D. M., Tanabe, K., \& Arnold, J. M. (1994). Early life history of Nautilus: Evidence from isotopic analyses of aquarium-reared specimens. Paleobiology, 20, 40-51.

Landman, N. H., Cochran, J. K., Slovacek, M., Larson, N. L., Garb, M. P., Brezina, J., et al. (2018a). Isotope sclerochronology of ammonites (Baculites compressus) from methane seep and nonseep sites in the Late Cretaceous Western Interior Seaway, USA: Implications for ammonite habitat and mode of life. American Journal of Science, 318, 603-639.

Landman, N. H., Grier, J. W., Cochran, J. K., Grier, J. C., Petersen, J. G., \& Towbin, W. H. (2018b). Nautilid nurseries: hatchlings and juveniles of Eutrephoceras dekayi from the lower Maastrichtian (Upper Cretaceous) Pierre Shale of east-central Montana. Lethaia, 51, 48-74.

Landman, N. H., Rye, D. M., \& Shelton, K. L. (1983). Early ontogeny of Eutrephoceras compared to recent Nautilus and Mesozoic 
ammonites: Evidence from shell morphology and light stable isotopes. Paleobiology, 9, 269-279.

Lécuyer, C., \& Bucher, H. (2006). Stable isotope compositions of a late Jurassic ammonite shell: a record of seasonal surface water temperatures in the southern hemisphere? eEarth Discussions, 1, $1-19$.

LeGrande, A. N., \& Schmidt, G. A. (2006). Global gridded data set of the oxygen isotopic composition in seawater. Geophysical Research Letters, 33, L12604.

Lemanis, R., Zachow, S., Fusseis, F., \& Hoffmann, R. (2015). A new approach using high-resolution computed tomography to test the buoyant properties of chambered cephalopod shells. Paleobiology, 41, 313-329.

Linzmeier, B. J., Kozdon, R., Peters, S. E., \& Valley, J. W. (2016). Oxygen isotope variability within Nautilus shell growth bands. PLoS One, 11, e 0153890.

Linzmeier, B. J., Landman, N. H., Peters, S. E., Kozdon, R., Kitajima, K., \& Valley, J. W. (2018). Ion microprobe-measured stable isotope evidence for ammonite habitat and life mode during early ontogeny. Paleobiology, 44, 684-708.

Liu, B., Chen, X., Chen, Y., Lu, H., \& Qian, W. (2011). Trace elements in the statoliths of jumbo flying squid off the Exclusive Economic Zones of Chile and Peru. Marine Ecology Progress Series, 429, 93-101.

Locarnini, R. A., Mishonov, A. V., Antonov, J. I., Boyer, T. P., Garcia, H. E., Baranova, O. K., Zweng, M. M., Paver, C. R., Reagan, J. R., Johnson, D. R., Hamilton, M., \& Seidov, D. (2013). World Ocean Atlas 2013, Volume 1: Temperature. In S. Levitus, A. Mishonov (Eds.), NOAA Atlas NESDIS 73 (p. 40).

Lukeneder, A. (2015). Ammonoid habitats and life history; p. In C. Klug, D. Korn, K. D. Baets, I. Kruta, \& R. H. Mapes (Eds.), Ammonoid paleobiology: From anatomy to ecology (Vol. 43, pp. 689-791). Topics in Geobiology, Dordrecht: Springer.

Lukeneder, A., Harzhauser, M., Müllegger, S., \& Piller, W. (2008). Stable isotopes $\left(\delta^{18} \mathrm{O}\right.$ and $\left.\delta^{13} \mathrm{C}\right)$ in Spirula spirula shells from three major oceans indicate developmental changes paralleling depth distributions. Marine Biology, 154, 175-182.

Lukeneder, A., Harzhauser, M., Müllegger, S., \& Piller, W. E. (2010). Ontogeny and habitat change in Mesozoic cephalopods revealed by stable isotopes $\left(\delta^{18} \mathrm{O}, \delta^{13} \mathrm{C}\right)$. Earth and Planetary Science Letters, 296, 103-114.

Martin, A. W., Catala-Stucki, I., \& Ward, P. D. (1978). The growth rate and reproductive behavior of Nautilus macromphalus. Neues Jahrbuch Fur Geologie Und Palaontologie, 156, 207-225.

McConnaughey, T. A., \& Gillikin, D. P. (2008). Carbon isotopes in mollusk shell carbonates. Geo-Marine Letters, 28, 287-299.

Meyers, S. R. (2014). Astrochron: An R package for astrochronology. http://cran.r-project.org/package=astrochron

Meyers, S. R., Sageman, B. B., \& Hinnov, L. A. (2001). Integrated quantitative stratigraphy of the Cenomanian-Turonian bridge creek limestone member using evolutive harmonic analysis and stratigraphic modeling. Journal of Sedimentary Research, 71, 628-644.

Moriya, K. (2015). Isotope signature of ammonoid shells; p. In C. Klug, D. Korn, K. De Baets, I. Kruta, \& R. H. Mapes (Eds.), Ammonoid paleobiology: From anatomy to ecology (Vol. 43, pp. 793-836). Topics in Geobiology, Dordrecht: Springer.

Moriya, K., Nishi, H., Kawahata, H., Tanabe, K., \& Takayanagi, Y. (2003). Demersal habitat of Late Cretaceous ammonoids: Evidence from oxygen isotopes for the Campanian (Late Cretaceous) northwestern Pacific thermal structure. Geology, $31,167-170$.

Moss, D. K., Ivany, L. C., Silver, R. B., Schue, J., \& Artruc, E. G. (2017). High-latitude settings promote extreme longevity in fossil marine bivalves. Paleobiology, 43, 365-382.
Naglik, C., Tajika, A., Chamberlain, J., Klug, C. (2015). Ammonoid locomotion. In C. Klug, D. Korn, K. De Baets, I. Kruta, \& R. H. Mapes (Eds.), Ammonoid paleobiology: From anatomy to ecology (Vol. 43, pp. 649-688). Topics in Geobiology, Dordrecht: Springer

Nakamura, Y. (1993). Vertical and horizontal movements of mature females of Ommastrephes bartramii observed by ultrasonic telemetry. In T. Okutani, R. K. O'Dor, \& T. Kubodera (Eds.), Recent advances in cephalopod fisheries biology (pp. 331-336). Tokyo: Tokai University Press.

O'Dor, R. (2002). Telemetered cephalopod energetics: Swimming, soaring, and blimping. Integrative and Comparative Biology, 42, 1065-1070.

O’Dor, R. K., Adamo, S., Aitken, J. P., Andrade, Y., Finn, J., Hanlon, R. T., et al. (2002). Currents as environmental constraints on the behavior, energetics and distribution of squid and cuttlefish. Bulletin of Marine Science, 71, 601-617.

O’Dor, R. K., Forsythe, J., Webber, D. M., Wells, J., \& Wells, M. J. (1993). Activity levels of Nautilus in the wild. Nature, 362, 626-628.

Oba, T., Kai, M., \& Tanabe, K. (1992). Early life history and habitat of Nautilus pompilius inferred from oxygen isotope examinations. Marine Biology, 113, 211-217.

Ohno, A., Miyaji, T., \& Wani, R. (2015). Inconsistent oxygen isotopic values between contemporary secreted septa and outer shell walls in modern Nautilus. Lethaia, 48, 332-340.

Passey, B. H., Robinson, T. F., Ayliffe, L. K., Cerling, T. E., Sponheimer, M., Dearing, M. D., et al. (2005). Carbon isotope fractionation between diet, breath $\mathrm{CO}_{2}$, and bioapatite in different mammals. Journal of Archaeological Science, 32, $1459-1470$.

Petersen, S. V., Tabor, C. R., Lohmann, K. C., Poulsen, C. J., Meyer, K. W., Carpenter, S. J., et al. (2016). Temperature and salinity of the Late Cretaceous Western Interior Seaway. Geology, 11, 903-906

Rexfort, A., \& Mutterlose, J. (2006). Stable isotope records from Sepia officinalis-A key to understanding the ecology of belemnites? Earth and Planetary Science Letters, 247, 212-221.

Sakamoto, T., Komatsu, K., Shirai, K., Higuchi, T., Ishimura, T., Setou, T., Kamimura, Y., Watanabe, C., \& Kawabata, A. (2018). Combining microvolume isotope analysis and numerical simulation to reproduce fish migration history. Methods in Ecology and Evolution, 10, 59-69.

Schöne, B. R., Wanamaker, A. D., Jr., Fiebig, J., Thébault, J., \& Kreutz, K. (2011). Annually resolved $\delta^{13} \mathrm{C}$ shell chronologies of long-lived bivalve mollusks (Arctica islandica) reveal oceanic carbon dynamics in the temperate North Atlantic during recent centuries. Palaeogeography, Palaeoclimatology, Palaeoecology, 302, 31-42.

Scotese, C. R. (1991). Jurassic and Cretaceous plate tectonic reconstructions. Palaeogeography, Palaeoclimatology, Palaeoecology, 87, 493-501.

Sessa, J. A., Larina, E., Knoll, K., Garb, M., Cochran, J. K., Huber, B. T., et al. (2015). Ammonite habitat revealed via isotopic composition and comparisons with co-occurring benthic and planktonic organisms. Proceedings of the National Academy of Sciences, 112, 15562-15567.

Sobarzo, M., Bravo, L., Donoso, D., Garcés-Vargas, J., \& Schneider, W. (2007). Coastal upwelling and seasonal cycles that influence the water column over the continental shelf off central Chile. Progress in Oceanography, 75, 363-382.

Taylor, B. E., \& Ward, P. D. (1983). Stable isotopic studies of Nautilus macromphalus Sowerby (New Caledonia) and Nautilus pompilius L. (Fiji). Palaeogeography, Palaeoclimatology, Palaeoecology, 41, 1-16. 
Tourtelot, H. A., \& Rye, R. O. (1969). Distribution of oxygen and carbon isotopes in fossils of Late Cretaceous age, Western Interior region of North America. Geological Society of America Bulletin, 80, 1903-1922.

van Leeuwen, S., Tett, P., Mills, D., \& van der Molen, J. (2015). Stratified and nonstratified areas in the North Sea: Long-term variability and biological and policy implications. Journal of Geophysical Research: Oceans, 120, 4670-4686.

Ward, P. D., Carlson, B., Weekly, M., \& Brumbaugh, B. (1984). Remote telemetry of daily vertical and horizontal movement of Nautilus in Palau. Nature, 309, 248-250.

Weidel, B. C., Ushikubo, T., Carpenter, S. R., Kita, N. T., Cole, J. J., Kitchell, J. F., et al. (2007). Diary of a bluegill (Lepomis macrochirus): daily ${ }^{13} \mathrm{C}$ and ${ }^{18} \mathrm{O}$ records in otoliths by ion microprobe. Canadian Journal of Fisheries and Aquatic Sciences, 64, 1641-1645.

Westermann, G. E. G. (1996). Ammonoid life and habitat; p. In N. H. Landman, K. Tanabe, \& R. A. Davis (Eds.), Ammonoid paleobiology (Vol. 13, pp. 607-707). Topics in Geobiology, New York: Plenum Press.

Westermann, B., Beck-Schildwächter, I., Beuerlein, K., Kaleta, E. F., \& Schipp, R. (2004). Shell growth and chamber formation of aquarium-reared Nautilus pompilius (Mollusca, Cephalopoda) by
X-ray analysis. Journal of Experimental Zoology Part A: Comparative Experimental Biology, 301A, 930-937.

Wright, N., Zahirovic, S., Müller, R. D., \& Seton, M. (2013). Towards community-driven paleogeographic reconstructions: Integrating open-access paleogeographic and paleobiology data with plate tectonics. Biogeosciences, 10, 1529-1541.

Zakharov, Y. D., Shigeta, Y., Popov, A. M., Velivetskaya, T. A., \& Afanasyeva, T. B. (2011). Cretaceous climatic oscillations in the Bering area (Alaska and Koryak Upland): Isotopic and palaeontological evidence. Sedimentary Geology, 235, 122-131.

Zakharov, Y., Shigeta, Y., Smyshlyaeva, O., Popov, A., \& Ignatiev, A. (2006). Relationship between $\delta^{13} \mathrm{C}$ and $\delta^{18} \mathrm{O}$ values of the Recent Nautilus and brachiopod shells in the wild and the problem of reconstruction of fossil cephalopod habitat. Geosciences Journal, 10, 331-345.

Zakharov, Y. D., Smyshlyaeva, O. P., Tanabe, K., Shigeta, Y., Maeda, H., Ignatiev, A. V., et al. (2005). Seasonal temperature fluctuations in the high northern latitudes during the Cretaceous Period: isotopic evidence from Albian and Coniacian shallowwater invertebrates of the Talovka River Basin, Koryak Upland, Russian Far East. Cretaceous Research, 26, 113-132.

Zumholz, K., Hansteen, T. H., Klügel, A., \& Piatkowski, U. (2006). Food effects on statolith composition of the common cuttlefish (Sepia officinalis). Marine Biology, 150, 237-244. 